Dorling, D. (2015)

Policy, politics, health, and housing in the UK

Policy and Politics, 43, 2, pp.163-80

Final version of Manuscript as submitted to the Journal

\title{
Policy, Politics, Health and Housing in the UK
}

Danny Dorling, School of Geography and the Environment, University of Oxford

\section{Introduction}

This paper is not written in the standard journal style because the events being discussed here are not conducive to the normal form or reflective debate. They are very recent, possible unprecedented, much of the analysis and commentary available to date can only be gleaned from journalistic sources and, as yet, we have little idea of what the likely outcome of recent events might be. Almost no previous academic analysis of the housing market included an assessment that included the possibility of what has recent occurred to the UK housing market.

This paper describes how housing wealth inequalities have grown rapidly in the UK following the events of 2008 due to changes in property and equity holdings. This can be explained by the way the housing system (particularly the mortgage system) worked under the post 2008- conditions, but it was not predicted. The paper claims there are serious social wide implications of these ranges ranging from social mobility through to population health. Clearly this is a matter of great immediate importance for policy and politics. One recent quotation sums up the growing sense of frustration:

\begin{abstract}
"We are in a housing crisis that extends from the homeless on the street well into the middle class. We have couples deciding not to have children because they do not have the space to house them. We have people paying extortionate rents, and the lowest rate of new home construction in almost a century. Yet ministers just sit there like gouty old men in the 19th hole..."
\end{abstract}

Cohen, 2013

There can be many different version of how our politicians got to what Nick Cohen describes at the $19^{\text {th }}$ hole when it comes to housing policy. Housing academics tend to agree that it was in the 1980s when otherwise apparently 'respectable' homepurchasing residents started to get into arrears on their mortgages. Rising mortgage arrears had been quite rare before Mrs. Thatcher's government took charge of the country (Burrows and Ford 1989, Ford 1989). In the 1960s and 1970s homeownership had spread as people in secure employment could both afford to pay mortgages and knew that they would be able to make 25 years of payments without missing a month. 
Rising home ownership was financially possible because home-buyers' jobs were largely secure and unemployment was low. That era of full employment is over and yet we often behave as if it were not when we talk about housing policy, housing finance and our personal security of tenure. We forget that building societies were established to help people build homes. Debts used to be taken out to pay for the actual costs of constructing houses.

Today mortgages mostly pay for the profit being taken out of the housing system by people who are securing finance for their old age through the housing need of younger generations. When an elderly person sells a home they purchased for $£ 4000$ for $£ 800,000$ and downsizes they are extracting a windfall. But that windfall is not some fortunate gift of nature, it is not caused by fruit fortuitously dropping from the teach as the phrase implies. A declining proportion of monies spent on housing, on rents and mortgages, is being used to build or maintain housing. On top of this a large number of better-off citizens are investing in buy-to-let mortgages to try to extract even greater 'windfalls' in future. Housing prices can rise beyond many peoples' ability to ever pay for them because of the anticipated future profits from renting them in perpetuity.

Rising homeownership coupled with secure employment and the provision of millions of newly built council homes in the 1950s and 1960s put the consumers of housing in a powerful position in Britain, but this was before the secure well-paid working class jobs mostly went, and before the council homes stopped being built and before private landlords again started to buy up housing which, formally, had often been someone's dream home. The transformation to the new landlord age began slowly with 1986 partprivatization of building societies into banks and the introduction of housing benefits which were paid directly to landlords. This transformation began under Mrs. Thatcher tenure of office. Private renters' tenancies were also made insecure by Acts of Parliament passed while she was Prime Minister, especially the 1988 Housing Act.

Today one in four families with children in Britain are living in a home owned by a private landlord. By the time this paper is published the proportion may be higher than that. The graph below, released by the Social Mobility and Child Poverty Commission (SMCPC, Figure 3.14, 2013) shows the acceleration in the rise in that proportion in very recent years. That acceleration has coincided with a huge transfer of wealth in Britain; a transfer occurring in just the last five years. Over a longer time period the homes in which roughly a fifth $(20 \%)$ of families with children live have been transferred from either being former council houses or privately owned homes to become the property of private landlords. The vast majority of that transfer has occurred most recently and, at the point of writing this paper, the greatest increase in the rate of transfer of housing wealth to the hands of a few has been within the year 2011-12. The steepest rise in the graph below has been the most recent rise. 
Figure 1: Households with children in private renting, \% in England 1984-2012

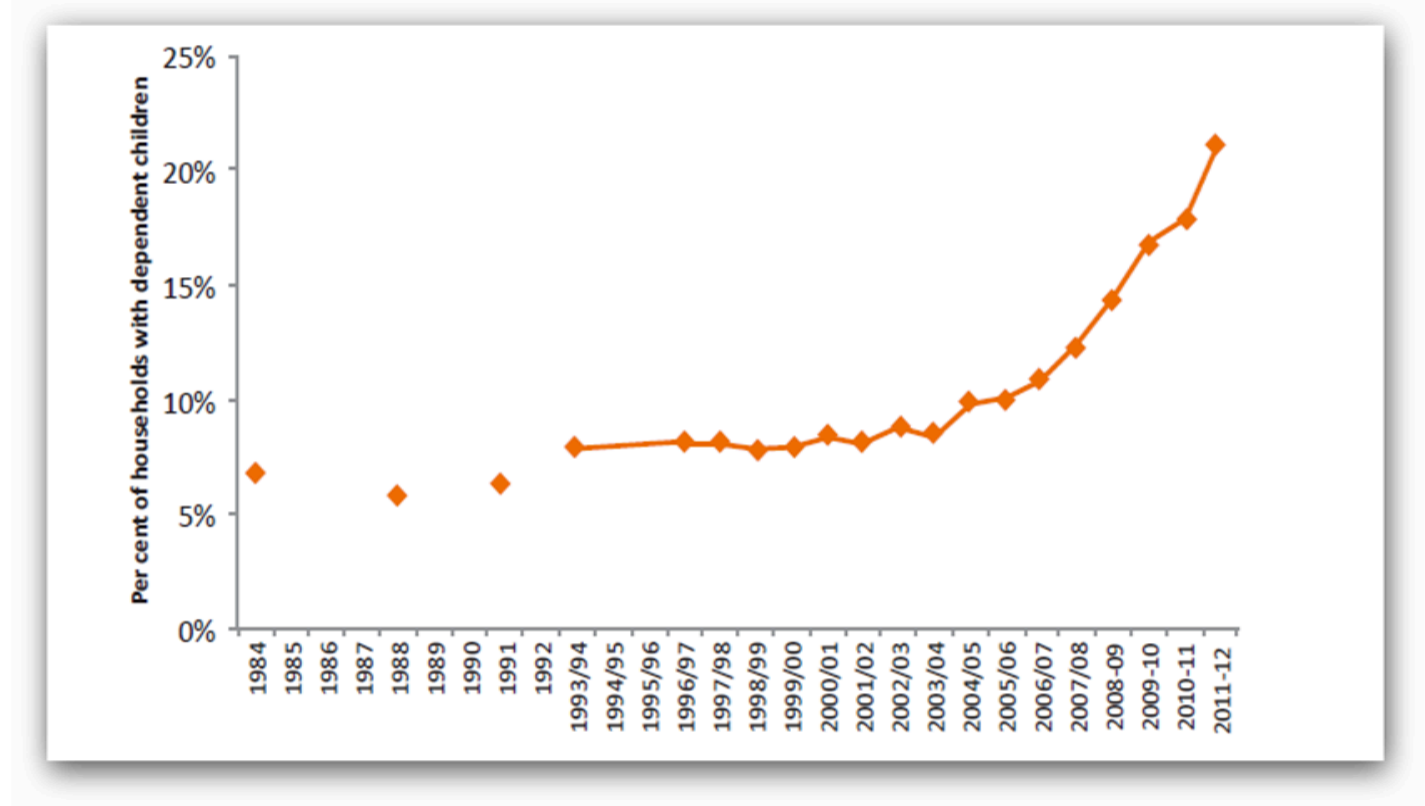

Source: Social Mobility and Child Poverty Commission (SMCPC, Figure 3,14, 2013)

In January 2014 the Financial Times released an analysis showing that over the course of just the last five years the equity of homeowners with mortgages in Britain had fallen by $£ 169$ billion while that of landlords had risen by a massive $£ 245$ billion. The estate agent Savills used geographical mortgage data at postcode level to determine that this had occurred and to measure the extent of equity transfer. Landlords' total growth in equity had more than doubled from $£ 384$ billion a decade ago to $£ 818$ billion by 2013 . The total equity of homeowners with mortgages had dropped by $£ 169$ billion because, on average, buyers now borrow more than they used to (Allen 2014). Landlords' wealth has risen rapidly because they can over-charge on rents and use their easy profits to quickly purchase more properties with cash or profitable mortgages. These sums of money are truly enormous even when put against the size of the UK annual deficit or gross national debt.

It is not immediately obvious how homeowner equity can fall by $£ 169$ billion and landlords simultaneously rise by $£ 245$ billion. The key factor to appreciate is that when homeowners pay off their mortgages, their equity ceases to be included, but would be replaced by the increasing equity of everyone else paying off a bit of their mortgages and the deposits of the new first time buyers. Those new deposits tend to be small in relation to the amount being borrowed so do not represent net assets coming into the system. Instead most of the money first time buyers could have saved while renting for their first deposit has gone into exorbitant rents. The ONS Wealth and Assets survey can be used to see the beginnings of this process, but it does not capture the most recent and most dramatic trends which the financial times revealed in early 2014 (Allen 2014). 
Over the last five years huge numbers of potential first time buyers have effectively end up spending on exorbitant rents more than enough for a first deposit several times over, but those monies are now kept by the landlord, who ploughs it back into purchasing even more property. In this way the landlords' equity can go up more than homeowners goes down. Furthermore, landlords are selectively buying where house prices are inflating fastest in the hope of even better capital returns. This process is strongest in places where the demand for housing is greatest. The landlords exacerbate the demand and so fuel housing price inflation there. As a result, their equity rises even more from inflation than the average homeowner with a mortgage. The total equity of people who owned their homes outright in Britain rose less than that of the tiny numbers who were landlords in the 2008 to 2013 period.

The policy response to the rapid rise in housing prices in the South East of England, which resulted from the buying spree of landlords, has been highly muted. The Conservative led coalition government plans to introduce Capital Gains Tax in nondomiciled overseas property owners after April 2015. The Labour Opposition have suggested bringing in a cap on the number of nonresident overseas buyers allowed to buy in the Capital or, at the very least, letting locals have the first option to buy, but still at the prices that landlords and other 'investors' have elevated the market to. By December 2013 the average price of a home in the UK had reached $£ 250,000$; the average price in London was $£ 450,000$. Both now represent multiples of average incomes never recorded as being so high before, or at least not record as being so high in the period since consistent records of house prices and average incomes have been made. By spring 2014 the land registry was reported average annual housing prices rise in London of $17 \%$, including of $4 \%$ in a single month.

Understandably the body representing landed interests, 'The British Property Federation', claimed that schemes to curb the growth in housing prices and rents currently being proposed or enacted "would not help anyone" (Booth, 2014). In a way, although defending the interest of their members, they are right. Politicians' current plans appear entirely inadequate as a means to alter the current direction of travel and suspicion is growing as to why that is. Among all the vested interests British members of parliament have, perhaps their greatest personal interest is in the value of their London property. This interest stretches across the political divide from the far left of parliament and Mr. Meacher's interests in the "London flats" he owns (maybe a dozen or more), through the New Labour years of home buying scandals (Mandelson's expensive new home and the Blair family flats and houses), right through to the property portfolios of many multi-millionaire landlords on the current government benches 
Various estimates suggest that at least a quarter of Members of Parliament have not only financial interests in owning expensive property but also in charging high rents to their tenants (Priced Out, 2014). Many MPs own multiple properties in London or the South East. Most of those that do have spare homes rent them out. We can't be entirely sure of the number because, remarkably, Members of Parliament are not required to list the capital gains they have made each year from property they have an interest in or how much they make in rent from their tenants. That is why organization such as "Priced Out" can only estimate the personal housing interests of politicians from collecting data on individual members of parliament from a variety of sources. There is no central record. Is it any wonder that the most significant element of the cost of living crisis - housing costs - is something MPs are so unenthusiastic about tackling?

\section{Background}

Before the 2008 financial crash the slow transformation of the British housing landscape had been so gradual that few noticed the change in the direction of travel. Mortgage holding had been falling since the mid-1990s, but this was initially thought to be due to demographic, not economic trends. In hindsight it was the beginnings of a trend that has been greatly accelerated by the outcome of the banking crash. Furthermore, the severity and depth of the crash led few to question what was then occurring. The mass media often appear to have a blind-spot to the underlying transformation of the market, or the insecurity of whole banking systems, at least until that insecurity becomes all too apparent.

As near to the UK as it is possible to get, the crash hit Ireland first and hardest. Before the crash in Ireland there was a resistance to see just how unstable the situation had become. In 2008 in Ireland '..prior to the bubble's collapse, the media made little mention of it, remained vague about it or tried to refute claims that it even existed, thus sustaining it' (Mercille, 2013). Today, in Ireland, there are countless areas of mass negative equity: 'For residents in these estates, they are living with the stress of an uncertain future with regards to works being completed, massive negative equity (in excess of $60 \%$ from peak), and a lack of a sense of place and community' (Kitchen et al. 2012, p.10). Perhaps it is partly the disaster of Ireland that caused some people in policy circles in Britain to be grateful that the landlords are so quickly buying up property in the South East of England. They might see this as preferable to homeowners and home-buyers experiencing an Irish, or Spanish, or Portuguese, or Greek, or Italian, or Icelandic style housing slump.

The events of 2008 became self-reinforcing and '...this self-reinforcing process was, in effect, a massive bank run that caused the shadow banking system to shrivel up, much as the conventional banking system did in the early 1930s' (Krugman, 2008, p.171). The 2008 outcome of banking instability led economists to become fearful. Housing was not worth as much as people had being paying for it. Either it had to fall in value or its recoverable value had to rise. One way in which its value could rise is if those who occupied the housing could never come to own it and so could be charged a rent in perpetuity for the right to live in the city. That rent could carry on being charged when the next set of tenants moved in and, if wages and salaries fell in response to the crash, which they did, then more and more people would be forced to rent and could not buy. 
Policy makers responded by claiming that they would make affordable homes available. Early in 2012 the then Conservative housing minister, Grant Shapps, and his Labour 'shadow' counterpart, Jack Dromey, had a very public argument about whether the coalition government was actually building a few hundred 'affordable homes' or not. They also came to blows over the demolition (under New Labour) of older housing in poorer parts of the North of England, some of which could perhaps have been preserved, the minister ' ... accused the previous Labour government of being second only to the Luftwaffe in destroying homes.' (Sergeant, 2012). In response Dromey, for Labour, made no pledge to reverse the trend towards a few private landlords owning more and more property, but lamented the advent of a 'generation rent'.

There was a surfeit of hypocrisy from all sides of the political divide. Politicians are often good and well-meaning people (Flinders, 2012) but it is when it comes to housing that they appear to be most vulnerable to twisted thinking and the lure of furthering personal gain while pretending to the electorate that they care. Perhaps it is because they so often own property in London - and so much other property in London is so much more expensive - that they do not realize how well off they often are. For example, Nick Boles, the UK coalition planning minister in 2012 said: 'I think everyone has the right to live somewhere that is not just affordable but that is beautiful and has some green space nearby ... a basic moral right, like healthcare and education. There's a right to a home with a little bit of ground around it to bring your family up in.' (Wintour, 2012).

The cynicism of Mr Boles statement, assuming for the sake of argument that he is not simply unable to see its intrinsic fallacy, is that it is not possible to house the current population of Britain, and especially London, all in a home with a little bit of ground around it, at least if the implication is that the ground is a garden for the private use of each family. In fact, it may well be the insistence on keeping the many little scraps of ground around homes in suburban London, and continuing to preserve nineteenth century low rise development in that Capital city, that deprives so many Londoners from having a chance to have a decent home, enough space to sleep in and eat in because others have gardens that they rarely use but which elevate the value of their London homes so much.

An interesting comparison to make is between London and Tokyo. Tokyo has is frequently ranked as the most expensive city in the world to live in and newspaper articles often repeat this claim. However in the 2013 international survey of housing costs made by the association of Japanese real estate appraisers (Nakaya 2014), like for like comparisons were made between the cost of buying a house in Kingston, London, verses an equivalent area such as Narita-higashi (in Suginami-ku, Tokyo). The typical home in Tokyo had a floor space of 150 square meters despite sitting on a site of just 200 square metres. In contrast, in London suburbia, a Kingston suburban housing plot might be twice as large including a garden, but the floor space of the average house there was only 140 square metres. The slightly larger house with smaller garden in Tokyo cost 100 million Yen as apposed to 157 million Yen for the house in Kingston, London. 
When comparing Tokyo and London apartments in the two cities vary even more in terms of the cost of buying. If a 70 square meter apartment in Toyotama-kita (in Nerima-ku Tokyo) is compared with an identically sized flat in the Battersea, the difference in cost of buying is immense: some 29 million Yen in Tokyo for a flat verses 88 million Yen in London - for the same sized apartment in a comparable location. The differences in rental costs are less, with that flat in Japan costing 2143 Yen per square meter to rent per year verses 3527 Yen for the same sized flat in London. Still, London is clearly far more expensive and thus may now be the most expensive large city in the world to try to live in. Furthermore the transport system is far more efficient in Tokyo so living a little further out of the city centre is not as inconvenient as it is in London in terms of hours wasted per day commuting.

Other world cities that compete for the title of "most expensive" include Oslo in Norway (ECA, 2013). However, such comparisons do not take into account the much higher salaries and wages in countries like Norway or Japan. Both countries not only have higher mean incomes than in the UK but their distribution of incomes are among the most even in the rich world, so housing in both Oslo and Tokyo is expensive, but more affordable to most people living in each city as compared to affordability in London for the median resident. There will be third world cities surrounded by shanty towns where the average affordability of good quality housing is even lower than in London, but within the rich world it will be hard to find a large city today where the proportion of their incomes that residents spend on rents or mortgages is higher than what was usual in London in 2014.

As London became the most expensive large city in the world to live in with regard to housing costs, the political and policy atmosphere began to change. During 2013 the value of average housing in the Capital rose by at least $£ 30,000$. That was by more than the median London income. By the end of summer 2013 the satirical magazine Private Eye remarked on how Grant Shapps, the Conservative Party Chairman and recent Minister of State for Housing, appeared to be strangely quiet about the possible benefits from house prices once again rising so quickly in the south of the country. The magazine's writer noted that in 2011 Shapps had suggested that price stability should be the aim of government policy, by which Shapps meant prices rising by $2 \%$ less than earnings (Sauce, 2013). Clearly housing was becoming both a policy nightmare and a political millstone at one and the same time.

There is an abiding sense among many older commentators that we have been here before. It is not so much the housing crash of 1989 and rising negative equity then, or the volatility of the 1970s from deflation, or even the austerity of the 1950s but an even earlier period that comes to mind: the 1920s and 1930s. It is the housing bubble that followed the ending of the First World War in the United States. With '...the war over in the fall [autumn] of 1918, a great shortage of space became evident. The average rents all over the country went up... $10 \%$ in $1918,20 \%$ in $1920,10 \%$ in 1921 , gradually increasing another $8 \%$ during 1922,1923 and 1924, reaching $168 \%$ of the pre-war base' (Harvey, 2012). The great crash of 1929 was preceded by the growth of a huge housing price bubble. What is most worrying and most different today is the growth of a housing bubble following the great crash of 2008 , not the one preceding it. 
The sense that something is fundamentally wrong is palpable across politics. A sense of economic crisis permeates the media in general and the arts in particular. 2013 also saw the release of Baz Luhrmann's film adaptation of F. Scott Fitzgerald's 1922 masterpiece, The Great Gastby. Many political and policy commentators remarked that again we are finding: '...the whole upper tenth of a nation living with the insouciance of grand dukes and the casualness of chorus girls.' This was how F. Scott Fitzgerald, author of the Great Gatsby, succinctly described the inequities of 1920s America in Tales of the Jazz Age (Fitzgerald, 1922). The sense of having been here before with the housing crisis we are currently in is accurate. We know that if you allow a tiny group of very affluent landlords to take over so much of the housing stock the results are far from good. So why do we do so little to counter this? Surely it cannot be just the personal corruption or inadequacies of our politicians? Maybe we do not realize how wide the ramifications of being housed so badly, so precariously, and so expensively are? To begin to understand that requires linking housing to health.

\section{Housing and health}

When there are financial crashes, often a consequent increase in anxiety is also recorded. The rapid rise in anxiety associated with the fear of joblessness was recorded in both 2008 and around the time of the 1929 crash (Stuckler et al., 2011a, 2011b). However, many people in the population who are not well housed also suffer increased insecurity and anxiety. Here is the story of one seven year old boy in the 1930s and what he remembers of the outcome of those times of the housing of his family and his friends in the USA:

'When I was seven years old my parents picked a house out of a booklet provided by a title company and bought it. They found the previous owners (mortgagees), who had long since defaulted on their mortgage, living there. It was a great hardship for the occupants to leave, they had no place to go. My parents had to have them evicted in order to move in. Many years later, I found the booklet and realized that about 20\% of the homes in the town were listed and many of my school classmates belonged to "squatter" families. It obviously benefited the banks and title companies to let people squat rather than let the properties fall into ruin and there was always the chance that they could repurchase their former homes. That was 1929. That is now.' Bob, Boonsboro, Maryland, (Saulny, 2012)

Of all the age groups it is perhaps the most elderly who are most susceptible to having their housing and personal social circumstances made very much more insecure very rapidly. The very elderly are not much affected by current educational problems, they tend not to be employed or affected when jobs are lost, except by the loss of jobs of others. In the UK Between 2008 and 2013 cuts have meant that (after taking demographic changes into account) probably around 483,000 old and disabled people in the UK have either lost their social care support or are no longer assessed as eligible for it. When the Personal Social Services Research Unit based at the LSE and the University of Kent the researchers emphasized that "Reductions in the number of clients are particularly acute for older people" (Fernandez et al, 2013). The graph below shows the timings of the cuts in visits to people needing help in their homes since $2007 / 8$, mostly cuts in visits to the elderly. 
Figure 2: Change in reported number of social care recipients, England (000s)

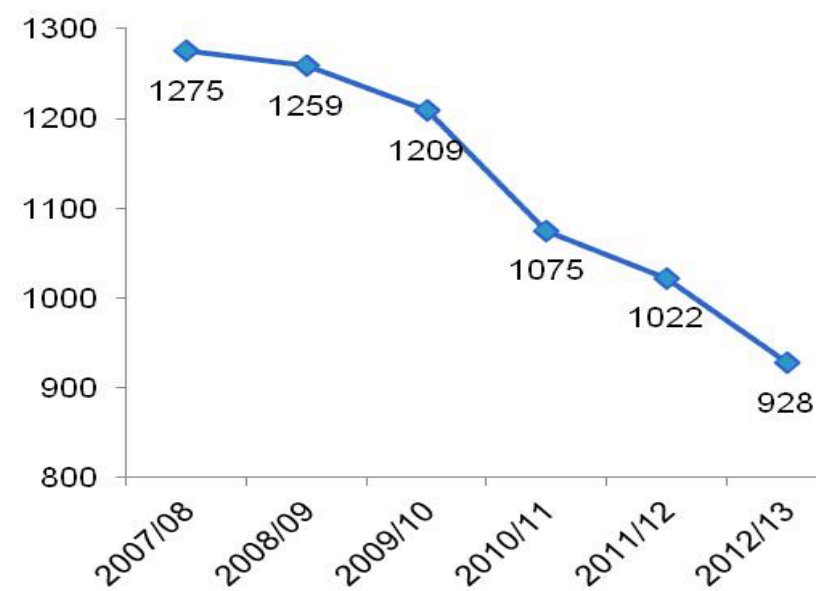

Source: Figure 1 of http://careandsupportalliance.wordpress.com/

Long before it became evident that visits to elderly people in England were falling across the UK, the housing of many elderly people was becoming rapidly more precarious. It is not just the young who increasingly suffer through how our housing and economy is changing. The announcement in July 2011 that the UK's largest private care home provider was about to go bankrupt and might need to close all 752 of its care homes was unlikely to have had only a minimal effect on the health of its elderly and frail customers. But that threat to elderly people's care-homes only occurred because the Coalition government in power did not intervene at an earlier stage. The BBC posted the story that some 31,000 care home residents were at risk of eviction as a piece of 'business news' rather than as a health story (BBC 2011). Two years later we saw life expectancy among the elderly fall in the UK. The next graph (Figure 3) gives an indication of the time of this and suggest that among the many factors that will invariably have been involved, the cuts in home visits to the elderly cannot be ruled out as having also had an impact.

Figure 3: Life Expectancy of Women aged 65 in the UK (years)

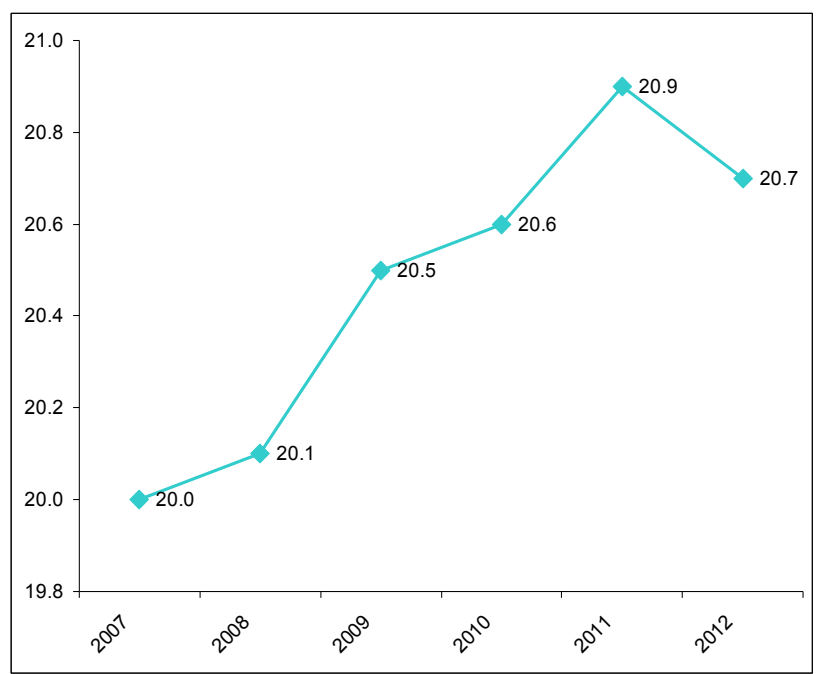

Source: Table A1.1 2012-based Expectation of Life, 1981-2062, Principal Projection, United Kingdom, December 2013 
Health, housing and inequality in wealth are intricately connected. From the United States we have quantitative evidence that finds that when '...examining the number of loans, black and Latino communities receive fewer loans than their white counterparts... [And] African American and Latino neighborhoods are almost five and two times more likely, respectively, to experience a homicide than white neighborhoods, holding all other variables constant...[We find] that black and Latino neighborhoods would experience fewer homicides if more financial capital were infused into these neighborhoods. These findings suggest that neighborhoods are shaped profoundly by the decisions of external economic actors.'( Veléz, 2009). From international studies we now know that countries with the lowest wealth inequalities - which usually translate into the lowest housing inequalities - also have the best health. The work of Nowatzki (2012) has shown this to be the case for people in general. She has found this to be the case through higher life expectancy and also for infants in particular as the next figure below illustrates.

Figure 4: Life Expectancy at birth and wealth inequality, 14 OECD countries, 2000

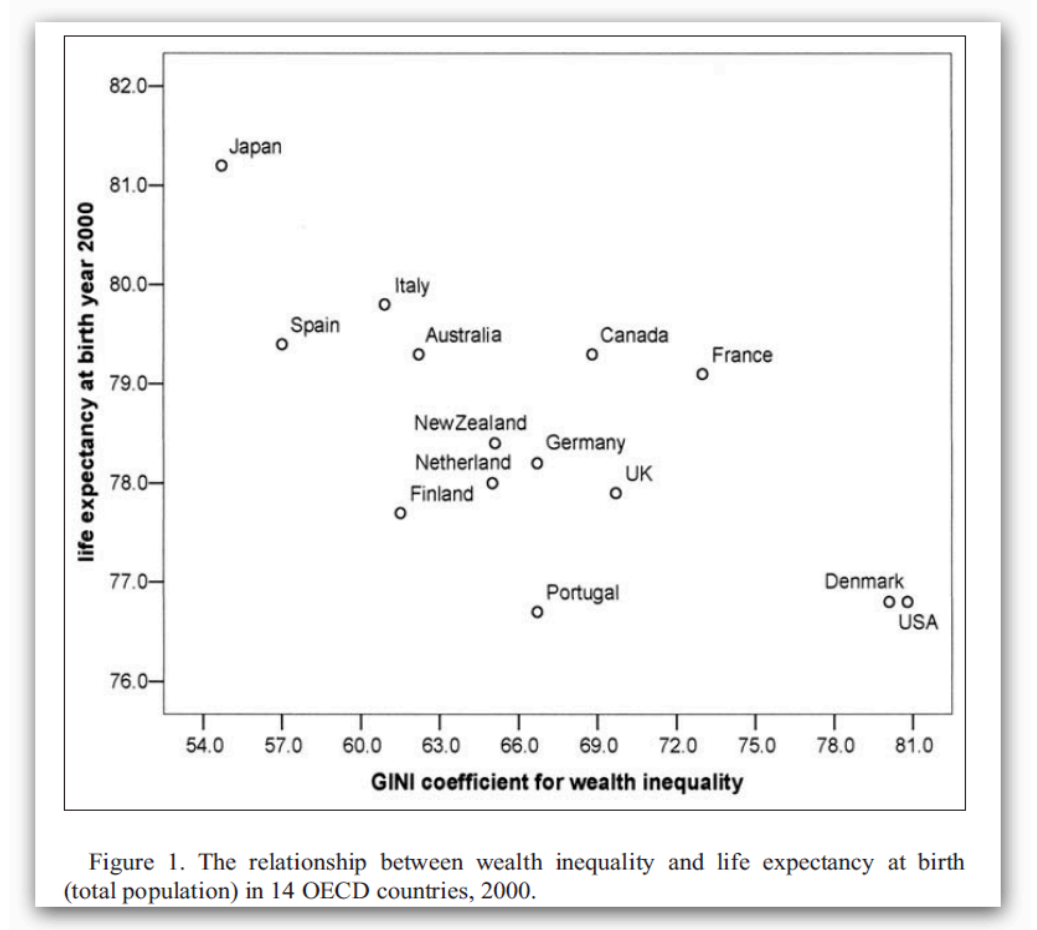

Source: Nowatzki, N.R. (2012) Wealth Inequality and Health: a Political Economy Perspective, International Journal of Health Services, 42, 3, 403-424.

There are likely to be many complex mechanisms through which high wealth inequality, and consequently poor housing, results in poorer overall health, but given these relationships (which are slowly being unpicked) we should not be surprised to find that as housing became more precariously provided in the UK, despite no great rise in unemployment, mortality began to rise particularly in some of the poorest areas for some of the most elderly people most recently. Housing, wealth, health, security, anxiety and sense of worth and of collective 
responsibility all appear to be intricately linked. Where the devil is allowed more often to take the hindmost, the hindmost more often dies early.

It was in England that rising mortality began to be recorded first during the later part of the year 2012. The Spearhead Areas of England were designated in 2004 using information on deprivation, mortality from cancer and heart disease as well as life expectancy to determine the places where people face the greatest health challenges. It was in those areas where elderly death rates rose the most during 2012; and by 2013 mortality rates for elderly were found to have been rising across most of the country. At first it was thought to be a cold winter and the flu. However it quickly became apparent that most of the increasing numbers of death were certainly not due to a flu epidemic, but also not due simply to the cold weather. If deaths were simply due to a cold winter, you would expect the rise to have little effect on residents of care homes that are almost always adequately heated. However, an increase in deaths from conditions that are likely to cause people to have been be admitted to residential care, such as dementia, would suggest that there has been a rise in residential care home deaths. And a large part of the recent rise has been an unexpected sudden increase in mortality attributed to dementia.

Now the rise in mortality has already occurred it is not possible to undertake the kinds of randomized trials physicians like to rely on to attribute cause. Doctors will tell you anecdotes that when old people are admitted to residential care homes, some die unexpectedly soon after. Relatives will tell you that they "lost the will to live", that they "just seemed to give up". "If we had known death would be so soon, we could have looked after them at home." But they did not know because their doctors did not know or did not expect it. However o doctor has ever written "lost the will to live" or "gave up" on a death certificate.

Coroners are quite happy to attribute suicide to a person's state of mind but only suicide. Could fear of the immediate future hasten death in the elderly? Could diminishing hope and growing despair be factors that can make the difference between a slightly longer life or an earlier death in the over $85 \mathrm{~s}$ ? These are issues coming to the fore now that we know that the rise, amounting to tens of thousands of unanticipated deaths in England, was definitely not simply due to flu or the cold weather.

What are the possible physical mechanisms for this increased mortality? Many. Take elderly residents in care homes; not bothering to tell staff of any new symptoms that might warrant some action. Take the staff; not noticing that someone appears unwell or just not bothering to ensure that they are drinking enough, because the staff are under greater pressure; after all they are finding it harder to feed themselves as their extremely low wages fall in real terms.

Governments can increase hope or despair not only by their actions but just by their attitudes. We now know that when Conservative Governments gain power in countries such as as the UK and Australia there is, on average, one more suicide a day among their electorates (Shaw et al 2002) . It is possible that any demoralizing effect from the election of the Coalition government was delayed due to initial uncertainty about what its true colour would be? After all, most of the cuts that have been undertaken and the reorganization of health and social 
care in their entirety were not manifesto promises. Nor was the rapid rise in the need to rely on food banks forecast. All that has happened so quickly will have come as a shock to many.

We are only just beginning to see all the possible connections between housing, society, inequality and health (Dorling, 2013). For instance, men have been found to be a third more likely to die after being recently widowed, compared with their normal risk of mortality. There is no doubt that emotional factors can cause deaths to rise from what appear initially to be more natural causes. A widespread increase in the number of deaths can be from a flu epidemic, or from exceptionally cold weather, from not being able to afford both adequate heating and adequate food, or from the meals-on-wheels person not arriving and noticing that you are ill. Most of these causes will not appear specifically on death certificates, but can be deduced by correlation. Among the very elderly in particular, many may have been from a growing sense of despair among that population. If growing despair is to blame then it would appear to be most damaging to those who are most often without partners and most frail: elderly women.

\section{Housing Policies}

As Becky Tunstall explained in her inaugural lecture as the new Director for the Centre for Housing in York (Tunstall, B., 2012). We urgently need to begin to worry about the increasingly inequitable distribution of housing in Britain. By 2011 the most spaciously housed tenth of the population had five times as many rooms per person than the most overcrowded tenth. This inequality in the provision of housing had never been greater (at least not since the census of 1911 and probably never).

Figure 5: Housing space consumption by population percentile, people in private households, England and Wales 1911-2001

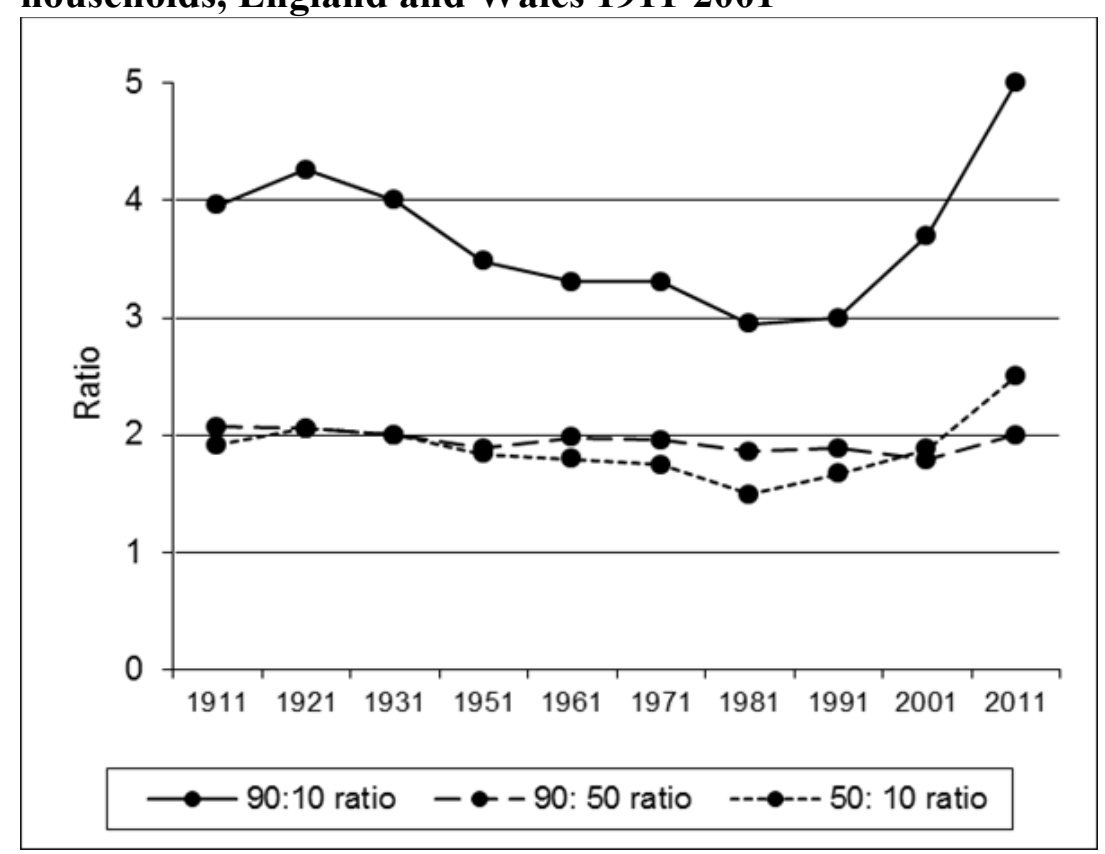

Source, Tunstall 2014, based on Censuses 1911-2011 (General Register Office 1913, 1925, 1935, 1956, 1964, Office of Population, Censuses and Surveys, 1974, www.casweb.mimas.ac.uk; www.nomisweb.co.uk). Note: the 90 th percentile is the most generously housed. 
So on policies, what has been the response? They have mostly been most punitive. The Prime Minister intends to take benefits from the under 25s (Brown, 2012). The Labour party suggest very similar policies, just a little more humane and beginning with the under 21s (BBC 2014) Housing is becoming most precarious for the under 30s who now have a right to be helped with housing in a bedroom in a shared property only if vulnerable. The bedroom tax has been applied to people living in social rented housing since 2013, causing large arrears to rise in rents, but as yet few evictions. To see where all this may be heading it can help to look to the USA where the outcome of many decades of growing income and then wealth inequalities is easier to see. In the USA: 'The stagnation of the living standards of the majority is not at all unrelated to the success at the top; in effect, those at the very top are plundering the poor and the middle classes. ... the market is at risk because extreme differences of power make a mockery of the voluntary nature of market transactions. The political system is at risk because plutocracy gradually replaces democracy.' (Deaton, 2013). Two decades earlier in the USA it was, at first, 'just' the homeless but who were seen as the problem, but even then the wider implications were beginning to be realized: "what we are dealing with here is not just "the problem of homelessness," but a million or more persons whose activity and dignity and freedom are at stake.' (Waldron, 1991, p.322)

In the UK recently the staid Institute for Fiscal Studies came out in favour of better land value taxation when it concluded that current: 'Taxation of land and property is inefficient and inequitable' (Mirrlees et al., 2011, p.481), and the Labour Party have suggested blocking overseas buyers. The model for blocking overseas investors comes from Switzerland where foreigners have to obtain a permit from the cantonal and federal authorities to purchase in popular areas and only 1440 homes a year can be sold to non-residents in these areas (Swiss property sales 2014). Once that limit is reached overseas buyers have to obtain Swiss Residency to purchase, and they must actually reside in the home and cannot rent it out.

To apply the Swiss system to Britain would be very difficult. Anyone who is an EU citizen has a right to reside and own property in Britain, just as the British have in the rest of the EU. For rich investors gaining EU citizenship is not difficult. Furthermore under existing British law the actual ownership of expensive property can be hidden through a company (Bilton, 2014). There are better ways to curb house price inflation than bans on foreign buyers.

So what is the UK government doing? It introduces the help to buy scheme, risking tax payer's money to underwrite $95 \%$ mortgages on property worth up to $£ 600,000$ in what may be one of the most cynical "homes for votes" scams ever undertaken. Ridiculed as "help for votes" or "help to bubble" even the website Conservative Home hosts articles titled: "Help to Buy is immoral because it encourages ordinary people to risk ruin" (Gimson, 2013). The only purpose the various government housing-schemes served in 2014 was to try to hold escalating home prices up in the South of England through to May 2015. So, we have to ask again, why is there so little debate among our politicians? Only $2 \%$ of the population were landlords in 2014 (as stated above, the estimate was made by Shelter), but at least a quarter of Member of Parliament are landlords (again as stated about, with the estimate made by Priced Out). 


\section{Conclusions}

Back when so much provision was not an entitlement, in 1921, it was possible for an academic to write that: 'No one has forgotten the opposition offered in the name of the rights of property to factory legislation, to housing reform ... Even to this day ... an English urban landlord can cramp or distort the development of a whole city by withholding land except at fancy prices, English municipalities are without adequate powers of compulsory purchase...' (Tawney, p. 26). We have again reached a point where the power of landlords needs to be addressed.

What is to be done? If a policy maker suggests raising property taxes then, almost immediately, people with expensive properties complain that they would find it hard to keep their 'family' homes open to the public to visit, or that they believed the tax encourages them to 'rip out our improvements and deliberately devalue' (Wood et al 2013). These are the kinds of comments that appear in the letters pages of the Telegraph Newspaper, but they appear to hold sway with the Coalition government of 2014. Similarly, when it comes to policies to reduce the growing income inequality that underlies many current housing woes, the current government in the UK opposes the limits being put on bankers' bonuses by the European Union because this might lead to some of the rich leaving London. They want the poor to leave instead, but bonuses have fallen. Some of it is used to buy homes for others to rent, and tenants will soon make up the majority of Londoners as a result (Whitehead et al 2012).

Another way is possible. Affordable private renting is possible. Statistics released during 2012 have shown that '...more than one quarter of the population in Germany, Denmark, the Netherlands, Sweden, Luxembourg and Austria lived in rented dwellings with a market price rent; this share rose to almost half (49.9\%) in Switzerland. The share of the population living in a dwelling with a reduced price rent or occupying a dwelling free of charge was less than $20 \%$ in all EU [European Union] Member States' (Eurostat, 2012). Alternatively, we move back in time and we begin to say again that people should not start a family if they cannot afford a home. The issue of people having babies to be able to secure welfare payments has at least a 180 year pedigree. That 'Chadwick' Royal Commission that examined the British poor law in 1832 was 'haunted [by] the image of women producing multiple bastards for profit' (Observation by Lyne Lees Hollen, made in 1990, quoted in Callanan Martin, K., 2008, p.55). We often blame people for wanting to be housed rather than our politicians for failing to provide housing.

Enough has been written on where current politics and policy will take us for the trends to be clear: 'Most inner London boroughs are likely to become almost entirely unaffordable to lowincome tenants on LHA [Local Housing Allowance] by 2016.... The areas which remain affordable are characterized by high rates of multiple deprivation and unemployment among the existing population. We conclude that the reforms will intensify the spatial concentration of disadvantage in the city, and increase the segregation of poor and better-off households within London' (Fenton, 2011, see also Fenton, A., et al. 2012). This academic work coupled with current lobbying from groups such as Generation Rent (2014) suggests that there are at least three things that can be done apart from ending "Help to buy" and exposing the selfinterest of politicians who are so often landlords: 
Firstly landlords and property investors are given tax incentives to buy-to-let in Britain that urgently need to be reduced to stop the market overheating. In 2013 the Chancellor announced that Capital Gains Tax will apply to profits made by overseas buyers on property after April 2015, but that will only influence the very top of the market, just like Labour's new proposals. Landlords currently benefit from a complex and wide range of tax reliefs that encourage them to buy more properties and force prices up. If these incentives were phased out and new loopholes blocked, that would dampen demand from those wanting to make a quick buck out of housing. Housing prices in the capital are so high because landlords have become so desperate to buy there because the greatest profit is to be made where the greatest further house price inflation is anticipated.

Secondly tenants need decent rights, at the very least to be able to have the right to transfer their tenancy agreement to a stable rental contract that gives them the right to stay for at least five years, as proposed by Shelter in 2012 (Shelter, 2012). Today, those one in four of all families with children in England who now live in private renting can be moved on with just two months' notice. It is important to reiterate that Shelter also estimates that $2 \%$ of people in Britain are landlords and also to remember, as the Financial Times revealed, that this tiny group increased their wealth due to holding property and collecting rents by $£ 434$ billion in just the last ten years (Allen, 2014). We have an image of there being many small landlords. Most landlords don't own that many properties, but landlords are not a large population group.

Thirdly we need to make better use of the housing we already have, not just build more homes. As of 2014 there are an estimated 15 million empty bedrooms in owner occupied properties in England. In this sector around half of all bedrooms are not slept in each night, compared with $10 \%$ amongst social renters and $16 \%$ for private renters (Hutchinson, 2014). Even within Inner London There are more bedrooms than people, with the number of unused properties growing each year in the heart of the capital. Rising house prices results in less efficient use of property. We have enough housing for every family to have a spare room, but not for many to also have spare homes (a longer version of this argument is given in Dorling 2014).

Attempts to sideline the poor in the USA show what the price of policy failure could be. Today in the USA: 'In poor black neighbourhoods, eviction is to women what incarceration is to men: a typical but severely consequential occurrence contribution to the reproduction of urban poverty.' - (Desmond, 2012, p. 88). If the private rented family market is allowed to continue to rapidly grow in Britain then we will head towards what is now common in the USA. We could see the imprisoned population of men, already the highest in Western Europe, rise towards what is typical in the far more social insecure USA. And we could see poorer women in Britain begin to experience what is now common in the USA: multiple evictions of themselves and their children. If we blame the poor more than the rich we have only ourselves to blame for the situation we will soon find ourselves in. 


\section{References}

K. Allen (2014) Personal Communication on "cash buyers versus mortgages, the Savills analysis", January 16th, published as K. Allen, Home buyers left behind in Britain's twospeed housing market, Financial Times, January $17^{\text {th }} \mathrm{http}: / / \mathrm{www} . \mathrm{ft} . \mathrm{com} / \mathrm{cms} / \mathrm{s} / 0 / \mathrm{ea} 516116-$ 7f92-11e3-94d2-00144feabdc0.html?siteedition=uk\#axzz2sjYwaeQP

BBC (2011) Southern Cross set to shut down and stop running homes, July 11th, http://www.bbc.co.uk/news/business-14102750

BBC (2014) Ed Miliband: Young jobless must train or lose benefits, June $19^{\text {th }}$, http://www.bbc.co.uk/news/uk-politics-27911518

Bilton, H. (2013) How to escape the offshore property tax trap, The Telegraph, January 4th, http://www.telegraph.co.uk/finance/personalfinance/expat-money/9760320/How-to-escapethe-offshore-property-tax-trap.html

Booth, R. (2014) Give local buyers first refusal on new homes, urges Labour: Labour's plan to tackle bulk-buying of properties by overseas investors is criticised by housing industry, The Guardian, February 7th, http://www.theguardian.com/money/2014/feb/07/local-buyersfirst-refusal-new-homes-labour

Brown, C. (2012) PM confirms age limit plan for housing benefit, Inside Housing, October 10th, http://www.insidehousing.co.uk/ihstory.aspx?storycode $=6524142$

Burrows, R. and Ford, J. (1998) Self-Employment and Home Ownership after the Enterprise Culture, Work, Employment \& Society, 12, 1, 97-119

Callanan Martin, K. (2008, p.55) Hard and unreal advice: Mothers, social science and the Victorian poverty experts, New York: Palgrave.

Cohen, N. (2013) A coalition of the complacent, The Spectator, 7th January, http://blogs.spectator.co.uk/nick-cohen/2013/01/a-coalition-of-the-complacent/

Deaton, A (2013) What's wrong with inequality? Review of Joseph Stiglitz (2012) 'The Price of Inequality', London: Penguin, as reviewed in The Lancet, 381, 9864, p. 362, 2nd February

Desmond, M. (2012, p. 88) Eviction and the Reproduction of Urban Poverty. American Journal of Sociology, 118, 1, 88-133

Dorling, D. (2013) Fairness and the changing fortunes of people in Britain, Journal of the Royal Statistical Society A, 176, 1, 97-128,

Dorling, D. (2014) All That Is Solid: The Great Housing Disaster, London: Allen Lane

ECA (2013) Tokyo knocked off the top spot in the list of the world's most expensive cities for expatriates, ECA news report June $6^{\text {th }}$, http://www.eca-

international.com/news/press_releases/7849/Tokyo_knocked_off_the_top_spot_in_the_list_ of_the_world_s_most_expensive_cities_for_expatriates\#.UwsP1OOKVca

Eurostat (2012) Housing Statistics, Data from October 2012, European Commission webpages:

http://epp.eurostat.ec.europa.eu/statistics_explained/index.php/Housing_statistics

Fenton, A. (2011) Housing Benefit reform and the spatial segregation of low-income households in London, University of Cambridge, (Alex is now based at the London School of Economics), an on-line copy of the report is here:

http://www.cchpr.landecon.cam.ac.uk/outputs/detail.asp?OutputID=240 
Fenton, A., Lupton, R., Arrundake, R. and Tunstall, R. (2012) Public housing, commodification, and rights to the city: The US and England compared, Cities (2012), http://dx.doi.org/10.1016/j.cities.2012.10.004

Fernandez, J-L, Snell, T. and Wistow, G. (2013) Changes in the Patterns of Social Care Provision in England: 2005/6 to 2012/13, Personal Social Services Research Unit, PSSRU, Discussion Paper 2867, December, http://www.pssru.ac.uk/archive/pdf/dp2867.pdf

Flinders, M. (2012) Defending Politics: Why Democracy Matters in the 21st Century, Oxford: OUP.

Fitzgerald, F. S. (1922) Tales of the Jazz Age, http://fitzgerald.narod.ru/crackup/056eeho.htm

Ford, J. (1989) Casual work and owner occupation, Work, Employment \& Society, 3, 1, 2948.

Generation Rent (2014) Renters' Manifesto, June $17^{\text {th }}$, http://www.generationrent.org/manifesto_launch

Gimson, A. (2013) Help to Buy is immoral because it encourages ordinary people to risk ruin, November 14th, http://www.conservativehome.com/thetorydiary/2013/11/help-to-buy-isimmoral-because-it-encourages-ordinary-people-to-risk-ruin.html

Harvey, D. (2012) Rebel Cities, London: Verso.

Hutchinson, M. (2014) We Don't Build Enough Houses, So Let's Get Better at Using the Ones We've Got, The Huffington Post, February 5th, http://www.huffingtonpost.co.uk/matthutchinson/uk-housing_b_4724375.html

Kitchin, R., O'Callaghan, S. and Gleeson, J. (2012) Unfinished estates in Post-Celtic Tiger Ireland, NIRSA Working Paper no. 67, http://ebookbrowse.com/nirsa-working-paper-67unfinished-estates-in-post-celtic-tiger-ireland-pdf-d312024595

Krugman, P. (2008) The Return of Depression Economics and the crisis of 2008, London: Penguin.

Mercille, J. (2013): The Role of the Media in Sustaining Ireland's Housing Bubble, New Political Economy, DOI:10.1080/13563467.2013.779652. A summary can be found at: http://www.social-europe.eu/2013/04/the-role-of-the-media-in-propping-up-irelands-housingbubble/

Mirrlees, S. et al (2011) Tax by Design, Oxford: Oxford University Press:

http://www.ifs.org.uk/mirrleesReview/design

Nakaya, T. (2014) international survey of housing cost by the association of Japanese real estate appraisers, Personla Communication, February.

Nowatzki, N. R. (2012) Wealth Inequality and Health: A Political Economy Perspective, International Journal of Health Services, 42, 3, 403-424, http://www.ncbi.nlm.nih.gov/pubmed/22993961

Priced Out (2014) Personal Communication (February).

Saulny (2012, comment below story) When Living in Limbo Avoids Living on the Street, New York Times, 3rd March, http://www.nytimes.com/2012/03/04/us/when-living-in-limbo-avoidsliving-on-the-street.html?ref=us\&_r=1\&

Sauce, HP, 'Cunning stunts', Private Eye , 23 August- 5 September 2013 , No. 1 , 347 , p. 9

Sergeant, M. (2012) Housing: The Grant Shapps v Jack Dromey row deconstructed, BBC News, 13 June, http://www.bbc.co.uk/news/uk-politics-18415715 
Shaw, M., Dorling, D. and Davey Smith, G. (2002) Editorial: Mortality and political climate: how suicide rates have risen during periods of Conservative government, 1901-2000, Journal of Epidemiology and Community Health, 56, (10): 722-7,

Shelter, (2012) Shelter calls for new kind of renting contract, Press release, http://england.shelter.org.uk/news/previous_years/2012/september_2012/Shelter_calls_for_ stable_rental_contracts

Social Mobility and Child Poverty Commission (2013) State of the Nation 2013 October 2013, London: The Stationery Office https://www.gov.uk/government/ uploads/system/uploads/attachment_data/file/251213/State_of_the_Nation_2013.pdf

Stuckler, D., Meissner, C., Fishback, P., Basu, S., and McKee, M. (2011a) Banking crises and mortality during the Great Depression: evidence from US urban populations, 19271939, Journal of Epidemiology and Community Health, published online March 24th. doi:10.1136/jech.2010.121376.

Stuckler, D., Basu, S., Suhrcke, M., Coutts, A., and McKee M, (2011b) Effects of the 2008 recession on health: a first look at European data, The Lancet, on-line: July 9th; 378(9786):124-5. doi: 10.1016/S0140-6736(11)61079-9.

Swiss Property Sales (2014) Yes, it is possible to buy a property in Switzerland as a nonresident, Website Accessed February 8th, http://www.swissproperty.co.uk/page769/BuyersGuide/Can-I-Buy-A-Property-In-Switzerland-

Tawney, R.H.(1961, first edition 1921) The Acquisitive Society, London: Collins.

Tunstall, B. (2012) Inaugural lecture, What should we worry about when we worry about housing problems? University of York, 30th April, http://www.slideshare.net/djgb500/inaugslides-final

Tunstall, B. (2014) Relative housing inequality: The decline and return of housing space inequality in England and Wales, 1911-2011, in press.

Veléz, M. B. (2009) Banks and the Racial Patterning of Homicide: A Study of Chicago Neighborhoods, International Journal of Conflict and Violence, 3, 2, 154-171, http://www.ijcv.org/index.php/ijcv/article/viewArticle/3

Waldron, J. (1991) Homelessness and the issue of Freedom, UCLA Law Review, 39, 295324, http://faculty.washington.edu/pembina/all_articles/Waldron\%201991.pdf

Whitehead, C. et al. (2012) Housing in Transition, London, Resolution Foundation, June 8th.

Wintour, P. (2012) We need to build houses on a third more land, says planning minister, The Guardian, 27th November, http://www.guardian.co.uk/society/2012/nov/27/housebuilding-needs-more-open-land

Wood, S. Fast, R. and Sochor, N. (2013) Letters to the Telegraph, 20th February , page 25, http://www.telegraph.co.uk/comment/letters/9881083/Ed-Milibands-mansion-tax-policythreatens-Britains-historic-homes.html 